\title{
POLITIK LUAR NEGERI REPUBLIK INDONESIA PADA MASA KONFRONTASI INDONESIA-MALAYSIA TAHUN 1963-1966
}

\author{
Yadi Kusmayadi * \\ Dosen Program Studi Pendidikan Sejarah FKIP-Universitas Galuh Ciamis \\ Jl. R. E. Martadinata No. 150 Ciamis, 46274 Jawa Barat
}

\begin{abstract}
ABSTRAK
Tindakan Indonesia dalam pengunduran diri sebagai anggota PBB pada tanggal 7 Januari 1965 ketika Malaysia dinyatakan menjadi anggota tidak tetap dewan keamanan PBB. Tujuan penulisan ini untuk menganalisi peristiwa terjadinya politik nuar negeri pada tahun 1963-1966. Metode penelitian ini menggunakan pendekatan historis. Politik luar negeri Indonesia pada masa konfrontasi Indonesia dengan Malaysia tahun 1963-1966 melenceng dari garis politik luar negeri bebas aktif. Namun jika dilihat dari sisi positif, tindakan Presiden Soekarno melakukan konfrontasi kepada Malaysia sangat tepat. Sesuai dengan garis kebijakan politik luar negeri Indonesia yang bebas aktif, Indonesia tidak menghendaki negara tetangganya menjadi antek-antek negara kolonialis dan imperialis. Apabila sebuah negara di Asia Tenggara dapat dikuasai oleh kekuatan kolonialis dan imperialis, maka wilayah tersebut akan dijadikan basis bagi penyebaran pengaruh mereka dan bahkan penguasaan mereka atas bangsabangsa dan negara-negara di sekitarnya. Jika dilihat dari sisi negatif, konfrontasi ini telah menyebabkan bangsa Indonesia melenceng dari garis kebijakan politik luar negeri bebas dan aktif. Terbukti pada waktu itu Indonesia menyatakan keluar dari keanggotaan di PBB, dan setelah itu ada kesan bahwa bangsa Indonesia dikucilkan dari pergaulan dunia internasional. Selain itu pula, peristiwa konfrontasi Indonesia-Malaysia ini dimanfaatkan oleh PKI untuk kepentingannya mendekatkan negara Indonesia dengan negara-negara komunis seperti USSR, Korea Utara dan RRC.
\end{abstract}

Kata Kunci: Politik Luar Negeri, konfrontasi Indonesia dan Malaysia

\begin{abstract}
Indonesia's actions in resignation as a member of the United Nations on 7 January 1965 when Malaysia was declared a non-permanent member of the UN security council. The purpose of this paper is to analyze the occurrence of national politics in the year 1963-1966. This research method uses a historical approach. Indonesia's foreign policy during the Indonesian confrontation with Malaysia in 1963-1966 deviated from the line of active free foreign policy. However, if viewed from the positive side, the action of President Soekarno to confrontation to Malaysia is very appropriate. In accordance with the line of active foreign policy of Indonesia, Indonesia does not want its neighbors to be agents of the colonialist and imperialist countries. If a country in Southeast Asia can be dominated by colonialist and imperialist forces, then the region will serve as a basis for the spread of their influence and even their control over the surrounding nations and nations. If viewed from the negative side, this confrontation has caused the Indonesian nation deviated from the line of free and active foreign policy. Evident at that time Indonesia declared out of membership in the United Nations, and after that there is the impression that the Indonesian nation is ostracized from the international community. In addition, IndonesiaMalaysia confrontation event is utilized by the PKI for its interests to bring the country of Indonesia with the communist countries such as the USSR, North Korea, and the PRC.
\end{abstract}

Keywords: Foreign Policy, confrontation of Indonesia and Malaysia

\footnotetext{
${ }^{*}$ Penulis Koresponden

E-mail address: yadikusmayadi@gmail.com doi:
} 


\section{PENDAHULUAN}

Sejarah telah menujukkan bahwa Indonesia mampu membebaskan belenggu penjajahan. Proklamasi Kemerdekaan Indonesia dikumandangkan pada 17 Agustus 1945 oleh Soekarno-Mohammad Hatta, merupakan puncak perjuangan panjang bangsa Indonesia. Hal ini tercermin dari peran Soekarno yang merupakan tokoh yang dapat mengambil tanggung jawab guna melangsungkan proklamasi kemerdekaan (di samping Mohammad Hatta). Soekarno-Hatta adalah lambang dari bangsa yang bersatu seperti yang telah dicita-citakan sejak dahulu. Meskipun telah melanjutkan perjuangan yang berat tahuntahun berikutnya, Soekarno menjadi tokoh yang mendominasi seluruh elemen kehidupan berbangsa dan bernegara.

Bangsa Indonesia melihat sikap Soekarno dari sosok seorang negarawan, founding father yang ingin membangun Indonesia dari kemajemukan. Pluralitas ideologi tergambarkan dalam konsep (utopis), yaitu NASAKOM. Soekarno merupakan tokoh yang dominan dalam panggung politik Indonesia sejak 1945 sampai tahun 1965. Hal ini diperjelas lagi lebih-lebih pada delapan tahun terakhir. Akan tetapi jauh sebelumnya Soekarno sudah menjadi terkenal sebagai pemikir juga aktivis dalam pergerakan nasional (Partai Nasional Indonesia). Soekarno mempunyai pandangan dan pemikiran politik tersendiri baik sebelum ataupun sesudah proklamasi kemerdekaan negara Indonesia.

Politik luar negeri dijalankan oleh Soekarno dilakukan demi kepentingan nasional. Pada era pemerintahannya, kepentingan nasional utama bagi bangsa Indonesia adalah pengakuan akan kedaulatan politik dan pembentukan identitas bangsa (nation building). Kepentingan nasional tersebut diterjemahkan dalam suatu kebijakan luar negeri, tujuannya mencari dukungan juga pengakuan terhadap kedaulatan bangsa, serta untuk menunjukkan karakter bangsa Indonesia kepada negara-negara lain.

Implementasi dari kepentingan nasional tersebut adalah melakukan hubungan bersama negara-negara di Asia-Afrika yang baru terbebas dari penjajahan. Kepentingan nasional untuk menunjukkan karakter adalah dengan menonjolkan karakter bangsa Indonesia sebagai bangsa mandiri dan tidak bersedia ada di bawah tekanan bangsa lain. Oleh sebab itu, pada masa kepemimpinannya, Soekarno sangat menolak semua bentuk penindasan oleh negara lain.
Sesuai dengan prinsip dan sifat politik luar negeri yakni bebas aktif, anti-imperialisme, dan anti-kolonialisme. Soekarno menolak seluruh bentuk imperialisme juga kolonialisme. Salah satu bentuk penolakannya terhadap imperialisme juga kolonialisme adalah dengan tindakannya yang konfrontatif terhadap pembetukan Federasi Malaysia oleh Inggris.

Pembentukan Unifikasi Malaysia menjadi pemicu pertikaian Indonesia dengan Malaysia. Soekarno beranggapan pembentukan Federasi Malaysia adalah proyek neo-kolonialisme (Nekolim) Inggris yang dapat membahayakan revolusi Indonesia. (Sekretariat Negara RI, 1981: 234)

Tanggal 20 Januari 1963, Dr. Subandrio menggunakan istilah konfrontasi guna merumuskan kebijakan politik luar negeri Indonesia kepada Malaysia. Dia membenarkan rumusan itu dengan mengatakan "Malaysia secara terbuka menjadi bawahan imperialisme dan bertindak dengan rasa permusuhan terhadap Indonesia”. Presiden Soekarno pun menegaskan bahwa "Indonesia akan melaksanakan kebijakan konfrontasi terhadap Malaysia. (Leifer, 1989: 116)

Untuk menghadapi rencana pembentukan Negara Unifikasi Malaysia, pemerintah Indonesia sudah mengupayakan jalan damai yaitu melalui perundingan (diplomasi). Hal tersebut terbukti dengan beberapa perundingan seperti Konferensi wakil Menlu di Manila, pada tanggal 9 April sampai 17 April Tahun 1963, pertemuan Tokyo yang dilakukan Presiden Soekarno dan PM Tunku Abdul Rahman pada tanggal 31 Bulan Mei sampai 1 Juni 1963. Selain itu, konferensi tingkat Menlu di Manila tanggal 1 Juni sampai 11 Juni 1963. (Panitia penulisan Sedjarah Deplu Negeri, 1971:275-276)

Perundingan atau jalan damai yang sudah diupayakan mengalami kegagalan dan Federasi Malaysia pun tetap dibentuk tanggal 16 September 1963. Hal tersebut dianggap oleh pihak Indonesia maupun Filipina sebagai pelanggaran, sebab tindakan Malaysia menyimpang dari hasil KTT Manila. Tanggal 16 September Tahun 1963, secara formal dimulai konfrontasi terhadap Malaysia. Hubungan diplomatik Indonesia dan Malaysia telah terputus pada 17 September 1963.

Bentuk-bentuk dan aspek-aspek konfrontasi pun beragam, misalnya dalam bentuk pernyataan-pernyataan dan demontrasi-demontrasi yang bersifat politis. Sementrara dalam 
dimensi ekonomi, bentuk konfrontatif kepada Malaysia dilakukan melalui pemutusan hubungan perekonomian dengan Malaysia. Dalam dimensi militer, Indonesia kemudian menempatkan pasukan militer reguler secara terbatas. Kebijakan tersebut menggambarkan sikap diplomasi yang cukup agresif dengan cara konfrontatif, inilah karakter politik luar negeri Indonesia pada pemerintahan Soekarno.

Setelah Federasi Malaysia hadir, upaya perundingan tetap dilakukan atas usulan juga bantuan dari negara-negara lain: Amerika Serikat, Filipina, Thailand dan Jepang. Upaya perdamaian dengan jalan diplomasi kemudian mengalami kegagalan. Perundingan terakhir yang dilakukan dengan mengadakan pertemuan antara Soekarno, Tunku Abdul Rahman, dan Diosdado Macapagal di Tokyo bulan Juni 1964. Setelah rentetan kegagalan upaya diplomasi tersebut, kemudian tidak ada lagi upaya lain untuk meyelesaikan sengketa, yang mengakibatkan konfrontasi berlangsung terus. Bahkan sebagai tanda kekecewaannya terhadap Dewan Keamanan Perserikatan Bangsa Bangsa. Diterimanya Malaysia sebagai anggota tidak tetap tanggal 7 Januari 1965, Indonesia kemudian mengundurkan diri dari PBB. Situasi demikian kemudian mengubah kebijakan paradigma politik luar negeri RI.

\section{METODE PENELITIAN}

Metode Penelitian yang dilakukan oleh penulis adalah metode historis atau metode sejarah, yaitu cara menguji juga menganalisis kesaksian sejarah untuk menemukan data yang valid, otentik dan dapat dipercaya, serta usaha sintetis atas data semacam itu menjadi kisah sejarah yang kredibel. (Louis Gottchalk, 1983: 32)

Menurut Ismaun (1984: 94) metode sejarah atau metode historis ini mengandung empat langkah penting atau teknik sebagai berikut :

1. Heuristik

Tahap ini ialah langkah permulaan bagi penulis dalam proses mencari juga mengumpulkan bahan-bahan informasi yang diperlukan yang berhubungan dengan permasalahan penulisan jurnal ilmiah.

2. Kritik

Kritik sejarah ialah penilaian kritis kepada data juga fakta sejarah yang sudah ada. Data juga fakta sejarah diproses menggunakan kritik sejarah. Hasilnya disebut bukti (evidence) sejarah. Bukti sejarah ialah kumpulan fakta dan informasi yang telah divalidasi, menjadi terpercaya sebagai bukti dasar yang baik guna menguji kemudian menginterpretasikan suatu permasalahan.

3. Interpretasi

Tahap ketiga, ialah interpretasi (penafsiran) analisis terhadap data juga fakta yang terkumpul. Prosedur ini digunakan untuk menafsirkan data dan fakta, menghubungkan berbagai data dan fakta serta membuat tafsirannya.

4. Historiografi

Setelah melakukan tahap-tahap didalam metode sejarah yakni mengumpulkan data, kritik data dan interpretasi maka sebagai tahap terakhir dari metode sejarah adalah penulisan sejarah.

\section{HASIL PENELITIAN DAN PEMBAHASAN}

\section{Konfrontasi Indonesia-Malaysia}

Konfrontasi Indonesia dengan Malaysia yang kemudian dikenal dengan politik Konfrontasi, ialah sebuah perang urat syaraf tentang masa depan Malaysia, Brunei, Sabah dan Sarawak. Hal ini terjadi antara Federasi Malaysia dan Indonesia pada tahun 1963 hingga 1966.

Perang ini berasal dari keinginan pemerintah Malaysia yang ingin membentuk Federasi Malaya (FM) atau lebih dikenal dengan Persekutuan Tanah Melayu. Tahun 1961 FM menggabungkan Brunei, Sabah dan Sarawak ke dalam wilayahnya. Hal ini tidak sesuai dengan Persetujuan Manila, maka keinginan itu ditentang oleh Presiden Soekarno. Soekarno menganggap pembentukan Federasi Malaysia (FM) yang sekarang dikenal sebagai Malaysia sebagai "boneka Inggris" yang merupakan kolonialisme dan imperialisme dalam bentuk baru. Dukungan terhadap berbagai gangguan keamanan dalam negeri dan pemberontakan di Indonesia. (Patrick Witton, 2003: 944)

Pelanggaran perjanjian internasional dengan konsep The Macapagal Plan melalui perjanjian Manila pada 31 Juli 1963, kemudian tanggal 3 Agustus 1963 juga tanggal 5 Agustus 1963 tentang dekolonialisasi yang harus mengikutsertakan seluruh rakyat Sarawak dan Sabah. 


\section{Latar Belakang}

Pada tahun 1961, Pulau Kalimantan dibagi empat administrasi. Borneo atau Kalimantan merupakan provinsi di Indonesia. Batas di sebelah utara ialah Kerajaan Brunei dan 2 koloni Inggris yaitu Sarawak dan Borneo Utara, selanjutnya Borneo Utara disebut Sabah. Bagian dari penarikan koloni Inggris di Asia Tenggara, ia (Inggris) mencoba menggabungkan koloninya di Kalimantan dengan Semenanjung Malaya dengan membentuk Federasi Malaysia.

Rencana pembentukan FM ditentang oleh Pemerintahan Indonesia. Presiden Soekarno beranggapan jika Malaysia ialah boneka Inggris dan jika Indonesia berkonsolidasi dengan Malaysia hanya akan menambah kontrol dan kekuasaan Inggris di kawasan Asia Tenggara, lebih jauh posisi ini bisa mengancam kemerdekaan Indonesia. Filipina akhirnya membuat klaim juga atas wilayah Sabah, dengan alasan Sabah memiliki hubungan sejarah dengan Filipina, melalui Kesultanan Sulu.

Di Brunei, kemudian Tentara Nasional Kalimantan Utara (TNKU) melakukan pemberontakan, tanggal 8 Desember 1962. TNKU berusaha menangkap Sultan Brunei, yang menguasai ladang minyak dan menyandera orang Eropa. Sultan Brunei berhasil lolos dan meminta pertolongan Inggris. Sultan Brunei menerima pasukan dari Inggris juga pasukan Gurkha dari Singapura. Tanggal 16 Desember, Komando Timur Jauh Inggris (British Far Eastern Command) mengklaim seluruh pusat pemberontakan telah diatasi kemudian tanggal 17 April 1963, pimpinan pemberontakan akhirnya ditangkap dan pemberontakan pun berakhir.

Filipina dan Indonesia kemudian secara resmi menyetujui pembentukan Federasi Malaysia jika mayoritas di daerah yang telah dilakukan dekolonialisasi memilih melalui referendum yang diorganisasi oleh PBB. Pada tanggal 16 September 1963, sebelum hasil dari pemilihan dilaporkan. Malaysia melihat pembentukan federasi sebagai masalah didalam negeri, tanpa turut campur orang luar, namun Indonesia melihat hal ini sebagai pelanggaran terhadap Persetujuan Manila dan adanya kolonialisme juga imperialisme Inggris.

Amarah Presiden Soekarno semakin besar semenjak demonstrasi mahasiswa Malaysia yang anti-Indonesia. Demontrasi tersebut berlangsung di Kuala Lumpur. Para mahasiswa (demonstran) berbondong-bondong datang ke gedung KBRI, disana mereka merobek-robek foto Presiden Indonesia, Soekarno, dan membawa lambang negara Indonesia Garuda Pancasila ke hadapan Tunku Abdul Rahman (Perdana Menteri Malaysia saat itu), kemudian memaksanya untuk menginjak lambang negara Indonesia.

Demonstrasi anti-Indonesia di Kuala Lumpur terjadi pada tanggal 17 September 1963. Hal ini terjadi karena luapan kemarahan mahasiswa Malaysia kepada Presiden Soekarno yang melakukan konfrontasi kepada Malaysia juga serangan pasukan militer Indonesia yang tidak resmi kepada Malaysia. Selanjutnya berbarengan dengan pengumuman Menlu Indonesia Dr. Soebandrio, Indonesia mengambil sikap untuk bermusuhan kepada Malaysia pada 20 Januari 1963. Selain itu penyusupan pasukan sukarelawan Indonesia (seperti: pasukan militer yang tidak resmi) akhirnya masuk ke Sarawak dan Sabah untuk menyebarkan propaganda juga melakukan penyerangan dan sabotase pada 12 April 1963. (Kusumah Hadiningrat, 1971: 59)

Presiden Soekarno kemudian marah, karena hal tersebut. Ia mengutuk tindakan demonstrasi anti-Indonesia yang menginjakinjak lambang negara Indonesia, Soekarno ingin balas dendam atas perbuatan mahasiswa Malaysia dengan melakukan gerakan "Ganyang Malaysia”. (Kompas, 29 September 2007) Presiden Soekarno kemudian selalu berbicara "Ganyang Malaysia" melalui pidato-pidatonya:

"Kalau kita lapar itu biasa Kalau kita malu itu juga biasa Namun kalau kita lapar atau malu itu karena Malaysia, kurang ajar! Kerahkan pasukan ke Kalimantan hajar cecunguk Malayan itu! Pukul dan sikat jangan sampai tanah dan udara kita diinjak-injak oleh Malaysian keparat itu. Doakan aku, aku kan berangkat ke medan juang sebagai patriot Bangsa, sebagai martir Bangsa dan sebagai peluru Bangsa yang tak mau diinjak-injak harga dirinya. Serukan serukan keseluruh pelosok negeri bahwa kita akan bersatu untuk melawan kehinaan ini kita akan membalas perlakuan ini dan kita tunjukkan bahwa kita masih memiliki Gigi yang kuat dan kita juga masih memiliki martabat.

Yoo...ayoo... kita... Ganjang...

Ganjang... Malaysia

Ganjang... Malaysia

Bulatkan tekad

Semangat kita badja

Peluru kita banjak 


\author{
Njawa kita banjak \\ Bila perlu satoe-satoe! \\ (Soekarno)."
}

\section{Lahirnya Kebijakan Dwikora}

Sejalan dengan perubahan zaman, arus gerakan nasionalisme dan kemerdekaan di daerah-daerah jajahan tidak dapat dibendung lagi. Inggris yang menyadari ini, mau tidak mau harus melepaskan pula daerah-daerah jajahannya dan memberikan self-government serta kemerdekaan.

Daerah Malaysia bagi Inggris ialah tempat dimana terdapat kepentingan-kepentingan ekonomi Inggris memiliki arti maupun jumlah. Di samping kepentingan Inggris di bidang ekonomi, dan terutama strategi pertahanan Inggeris, daerah Malaysia merupakan salah-satu mata rantai yang penting dari pada garis pertahanan-pertahanan Inggris yang membentang dari Inggris melalui Gibraltar dan Aden terus ke Singapura sampai ke New Zealand. (Disjarah TNI AD, 1972 : 475)

Berhubungan dengan hal itu, maka Pemerintah RI menarik beberapa kesimpulan tentang mengapa Inggris sangat mendukung rencana pembentukan Malaysia, yakni Malaysia oleh Inggris direncanakan untuk dijadikan wilayah yang menjamin kelangsungan kepentingan-kepentingan Inggris di bidang ekonomi, pertahanan, serta Malaysia diperkirakan akan tetap berhaluan pro Barat.(Kusumah Hadiningrat, $1971: 1$ )

Dengan dasar penelaahan fakta-fakta serta pengenalan akan sifat-sifat serta siasat Inggris pada khususnya, dan Barat pada umumnya, maka Pemerintah RI berpendapat bahwa pembentukan Malaysia itu merupakan bahaya yang dapat mengancam pintu gerbang Indonesia. Oleh karena itulah, maka Pemerintah RI menentang pembentukan Malaysia melalui konfrontasi, dengan alasan-alasan prinsip dan keamanan.

Walaupun sudah sedemikian rupa persengketaan Malaysia tersebut, Soekarno bersama Presiden Philipina Diosdado Macapagal, masih terus berusaha agar Tengku Abdul Rachman dan kawan-kawan yang dianggap oleh kedua negara tersebut sebagai antek-antek Nekolim (Neo Kolonialisme) kembali pada Manilla Agreement (Pertemuan Manila), demi keutuhan rumpun rakyat Melayu. Maka pada bulan Juni 1964 diadakan Konferensi Tingkat Tinggi di Tokyo (KTT-Tokyo), dalam hal ini pun Tengku Abdul Rachman dan kawan- kawan menampakkan ketidaksungguhannya guna menyelesaikan permasalahan Malaysia, hal itu jelas kelihatan dari sikap politiknya. (Departemen Penerangan, 1964 : 71-72)

KTT Tokyo tersebut mengeluarkan suatu pernyataan, dan beberapa poin dari pernyataan bersama itu ialah pembentukan suatu Komisi Pendamai Asia Afrika yang terbagi menjadi 4 anggota, tiga diantaranya akan dipilih masingmasing oleh Indonesia, Philipina dan Malaysia, dan satu negara lagi (keempat) akan dipilih secara bersama-sama oleh ketiga anggota Asia Afrika dari komisi tersebut. Komisi ini akan diminta untuk mempelajari masalah-masalah yang ada antara ketiga negara yang bersangkutan dan akan menyampaikan rekomendasi untuk menyelesaikan permasalahan mereka. (Abdul Haris Nasution, 1966 : 196)

Hubungan permasalahan penyelesaian sengketa, maka bangsa Indonesia telah memperlihatkan jati dirinya sebagai bangsa yang cinta damai. Hal ini nampak mulai dari "Manilla Agreement" sampai dengan KTT Tokyo, karena kemerdekaan dan perdamaian adalah syarat mutlak bagi kemajuan umat manusia dan tercapainya kerangka ketiga Revolusi Bangsa Indonesia. Karenanya rakyat Indonesia berusaha keras untuk mensukseskan Dwikora, dengan membubarkan proyek Nekolim Malaysia. Oleh karena itulah kemudian Soekarno sebagai Presiden bertindak tegas menghadapi permasalahan tersebut.

Menindaklanjuti pernyataan Menlu Republik Indonesia Dr. Soebandrio, pada tanggal 20 Januari 1963. Indonesia mengambil sikap berhadapan kepada Malaysia. Tanggal 3 Mei 1964 sebuah rapat akbar digelar di Jakarta dan Presiden Soekarno mengumumkan perintah Dwi Komando Rakyat (Dwikora) yang isinya:

“1) Pertinggi ketahanan revolusi Indonesia.

2) Bantu perjuangan revolusioner rakyat Malaya, Singapura, Sarawak dan Sabah, untuk menghancurkan Malaysia. (Sekretariat Negara RI, 1981: 247)"

Pada tanggal 27 Juli 1964, Soekarno mengumumkan akan meng-"ganyang Malaysia". Pada tanggal 16 Agustus 1964, pasukan dari Resimen Askar Melayu DiRaja harus berhadapan dengan 50 gerilyawan Indonesia. Filipina tidak turut serta dalam perang, namun mereka hanya memutuskan hubungan diplomatik dengan Malaysia. Federasi Malaysia resmi dibentuk pada tanggal 16 September 1963. Brunei kemudian menolak 
bergabung dan Singapurapun keluar dari FM di kemudian hari.

Ketegangan kemudian berkembang di kedua belah pihak di wilayah Selat Malaka. Dua hari para demonstran dari Indonesia membakar kedutaan besar Inggris di Jakarta. Ratusan pendemo menduduki kedutaan besar Singapura di Jakarta, juga rumah diplomat Singapura. Sementara itu, di Malaysia, agen Indonesia berhasil ditangkap dan massa Malaysia menyerang kedutaan besar Indonesia di Kuala Lumpur.

Di sepanjang perbatasan Kalimantan, terjadi peperangan; militer Indonesia juga pasukan tidak resminya (sukarelawan) berusaha menduduki Sarawak dan Sabah, namun tanpa membuahkan hasil.

Pada tahun 1964 militer Indonesia menyerang wilayah Semenanjung Malaya. Pada bulan Mei Soekarno membentuk Komando Siaga yang bertugas mengkoordinir perang terhadap Malaysia (Operasi Dwikora). Komando ini kemudian berubah nama menjadi Komando Mandala Siaga (Kolaga). Kolaga kemudian dipimpin oleh Laksdya Udara Oemar Dani sebagai Pangkolaga. Kolaga terdiri dari tiga Komando, yaitu Komando Tempur Satu (Kopurtu) berkedudukan di Sumatera; terdiri dari 12 Batalyon TNI-AD juga tiga Batalyon Para dan satu batalyon KKO. Komando ini mempunyai sasaran operasi ke Semenanjung Malaya. Dipimpin oleh Brigjen Kemal Idris sebagai Pangkopur-I. Kemudian komando Tempur Dua (Kopurda) berada di Bengkayang, Kalimantan Barat; terdiri dari 13 Batalyon berasal dari KKO, AURI, dan RPKAD. Komando ini dipimpin oleh Brigjen Soepardjo sebagai Pangkopur-II. Selanjutnya komando ketiga ialah Komando Armada Siaga; terdiri dari TNI-AL juga KKO. Komando ini dilengkapi dengan Brigade Pendarat yang beroperasi di perbatasan Riau juga Kalimantan Timur.

Pada bulan Agustus, 16 agen bersenjata Indonesia ditangkap di Johor, kemudian aktivitas Militer Indonesia di perbatasan meningkat. Tentara Laut DiRaja Malaysia kemudian mengerahkan pasukan untuk mempertahankan Malaysia. Tentara Malaysia sedikit yang diturunkan dan mereka harus bergantung kepada pos perbatasan dan pengawasan unit komando. Misi utama mereka ialah mencegah masuknya pasukan Indonesia ke Malaysia. Sebagian besar pihak yang terlibat konflik bersenjata dengan Indonesia ialah Inggris dan Australia. Terutama pasukan khusus mereka yakni Special Air Service (SAS). Tercatat sekitar 2000 angkatan bersenjata Indonesia tewas dan 200 pasukan Inggris/Australia (SAS) juga tewas ketika bertempur di hutan belantara kalimantan (Majalah Angkasa Edisi 2006).

Tanggal 17 Agustus 1964 pasukan terjun payung Indonesia berhasil mendarat di wilayah pantai barat daya Johor, kemudian mereka mencoba membentuk pasukan gerilya, tanggal 2 September 1964 pasukan terjun payung didaratkan lagi di Labis, Johor. Tanggal 29 Oktober, 52 tentara Indonesia berhasil mendarat di Pontian; perbatasan Johor-Malaka, mengalahkan pasukan Resimen Askar Melayu DiRaja dan Selandia Baru juga menumpas Pasukan Gerak Umum Kepolisian Kerajaan Malaysia di Batu 20, Muar, Johor.

Ketika PBB menerima Malaysia sebagai anggota Dewan Keamanan tidak tetap, Presiden Soekarno dengan tegas menarik Indonesia dari keanggotaan PBB. Hal ini terjadi pada tanggal 20 Januari 1965, akhirnya Indonesia mencoba membentuk Kekuatan Baru bernama Conference of New Emerging Forces atau "Conefo" sebagai alternatif. Sebagai tandingan Olimpiade oleh dunia Internasional, Soekarno kemudian menyelenggarakan GANEFO (Games of the New Emerging Forces), kegiatan ini diselenggarakan di Indonesia, tepatnya di Senayan, Jakarta tanggal 10 sampai 22 November 1963. Acara pesta olahraga besarbesaran ini diikuti sekitar 2.250 atlet dari 48 negara dari Asia, Afrika, Eropa dan Amerika Selatan, juga diliput oleh 500 wartawan asing.

Pada bulan Januari 1965, Australia menyetujui pengiriman pasukan ke wilayah Kalimantan, setelah menerima permintaan dari Malaysia. Australia mengirimkan 3 Resimen Kerajaan Australia dan Resimen Australian Special Air Service. Sekitar 14.000 pasukan Inggris juga negara persemakmuran Australia. Secara resmi, militer Inggris juga Australia tidak bisa mengikuti penyerangan melalui perbatasan Indonesia. Namun, unit Special Air Service, Inggris dan Australia, masuk secara rahasia.

Pada pertengahan tahun 1965, Indonesia mulai menggunakan militer resminya. Tanggal 28 Juni 1965, mereka menyebrangi perbatasan, kemudian masuk ke timur Pulau Sebatik dekat Tawau, Sabah lalu berhadapan dengan Resimen Askar Melayu Di Raja juga Kepolisian North Borneo Armed Constabulary.

Pada tanggal 1 Juli 1965, pasukan Indonesia yang berkekuatan sekitar 5.000 orang 
menyerang pangkalan Angkatan Laut Malaysia di Semporna. Kemudian serangan dan pengepungan terus dilakukan sampai 8 September, namun serangan itu mengalami kegagalan. Peristiwa ini kemudian dikenal oleh warga Malaysia dengan "Pengepungan 68 Hari".

Pada saat berlangsungnya konfrontasi Indonesia-Malaysia, Indonesia membentuk beberapa operasi Dwikora, di antaranya sebagai berikut.

a. Komando Siaga (KOGA)

Perkembangan situasi politik

Indonesia maupun di Malaysia sendiri serta akibat kegagalan diplomasi, Inggris mengumumkan bahwa negaranya siap untuk mengirimkan kekuatan militer dalam skala besar ke Malaysia. Untuk mengimbangi usaha-usaha di bidang diplomatik dan peningkatan bidang militer, maka dengan SK Presiden/ PANGTI ABRI/Panglima KOTI tanggal 2 Juni 1964 dibentuklah Komando Gabungan dengan nama KOMANDO SIAGA (KOGA) dengan tugas pokok :

"Dalam pelaksanaan DWIKORA merencanakan, mempersiapkan dan pada waktunya menyelenggarakan operasi-operasi serangan Balasan (retaliation) terhadap daerah lawan serta unsur-unsur lawan lainnya". (Dinas Sejarah TNI-AD, 1972: 476)

Presiden menunjuk Panglima Angkatan Udara sebagai Panglimanya, tetapi organisasi itu belum dapat dikembangkan sesuai dengan tugasnya, karena Komando Siaga belum mempunyai penelaahan dan perkiraan intelijen serta belum mempunyai fasilitas Markas dan lain-lainnya tanpa penjabat dan personil pembantu staf yang lengkap. Karena Panglimanya adalah Panglima Angkatan Udara, maka KOGA bermarkas di Komando Operasi Angkatan Udara RI di Lanud Halim Perdanakusumah. Baru setelah Malaysia dengan bantuan Inggris meningkatkan kekuatan dan kegiatan militernya, tanggal 2 September 1964 ditetapkanlah pejabat-pejabat Komando Siaga sebagai berikut :

1) Wakil Panglima I : Laksamana (L) Muljadi.

2) Wakil Panglima II : Brigjen TNI Achmad Wiranatakusumah.

3) Kepala Staf : Komodore Udara Leo Wattimena.

\section{b. Operasi "A"}

Sebelum pembentukan dan penugasan Komando Siaga dalam rangka konfrontasi terhadap Malaysia, sejak permulaan tahun 1963 Indonesia sudah mempersiapkan peningkatan usaha-usaha di bidang militer untuk mengimbangi situasi dan kondisi politik yang semakin meningkat. Untuk mengumpulkan data-data tentang kegiatan dan gerak-gerik lawan, maka pemerintah Indonesia mulai melaksanakan operasi intelijen yang dikenal dengan sebutan "Operasi A". Kegiatan operasi intelijen ini diikuti dengan Operasi "Lintas Bebas" yaitu operasi penyusupan gerilyawan ke daerah Malaysia dengan maksud guna mendirikan kantung gerilya di daerah-daerah musuh. Kedua bentuk operasi ini dilaksanakan dibawah pimpinan Komando Tertinggi (KOTI).

Untuk mendapatkan struktur pertahanan negara lebih kuat maka dibentuklah beberapa Komando Khusus seperti KOHANUDNAS (Komando Pertahanan Udara Nasional), KOANSUS (Komando Anti Subversif), KOPANNAS (Komando Pertahanan Pantai Nasional). Daerah-daerah berbatasan langsung Malaysia ditingkatkan kesiapsiagaannya secara fisik dan mental. Jaringan komunikasi dan pertahanan di Sumatera dan Kalimantan diperkuat terutama daerah Kalbar dan Kaltim: yang langsung berbatasan dengan daerah Kalimantan Utara yang diperkirakan sebagai daerah sasaran subversi dan kemungkinan pecahnya perang secara terbuka.

Dalam pelaksanaan tugasnya, Komando Siaga tanggal 25 Agustus 1964 telah menyusun suatu penelaahan tentang "Tugas Komando Siaga" yang mengemukakan pentingnya suatu integrasi dari semua tugas-tugas operasi DWIKORA. Hal ini penting karena setelah pembentukan dan penugasan Komando Siaga, KOTI masih terus melaksanakan operasi " $A$ " maupun operasi "Lintas Bebas" sehingga dirasakan adanya semacam dualisme dalam pelaksanaan operasi. Maka, untuk melaksanakan tugasnya, KOGA tidak menerima informasi dan perkiraan intelijen dari KOTI yang melaksanakan operasi "A". Kepala Stap Gabungan I KOTI yang dipegang oleh Dr. Subandrio yang juga sebagai Ketua Badan Pusat Intelijen (BPI) 
pada umumnya tidak memberikan informasi yang terperinci kepada KOGA dengan alasan "top secret" atau sangat rahasia.

Tanggal 1 September 1964 Komando Siaga menyusun Gagasan Strategi dan Tugas KOGA yang antara lain mengemukakan :

1) Perkiraan perimbangan kekuatan antara kita dengan lawan yang sangat tak menguntungkan.

2) Satu-satunya faktor yang menguntungkan ialah faktor man power, akan tetapi sangat kurang/tidak adanya mobility taktis maupun strategis.

3) Diperlukan tindakan cepat guna mendekatkan pasukan ke arah sasaran untuk memungkinkan mobility apabila diperlukan.

\section{c. Operasi "JALADARA"}

Dalam melaksanakan gagasan strategi KOGA tersebut, maka tanggal 31 Oktober 1964 dikeluarkanlah Petunjuk Operasi JALADARA No. POPS-03/1964 dan Instruksi Operasi No. INSOP-05/1964 tanggal 21 Nopember 1964. Operasi ini bertujuan untuk pemindahan dan penggeseran pasukan untuk pertahanan daerah Kalbar yang dimulai dengan pemindahan pasukan Jonif 521/Brawijaya ke daerah Kalimantan Barat.

Untuk menutupi tindakan penggeseran pasukan ini, maka dengan PO. JALADARA dilaksanakanlah suatu latihan gabungan pendaratan di Kalbar dengan mendaratkan JON 521 sebagai unsur kekuatan KOGA pada tanggal 24 Nopember 1964 yang kemudian menjadi Task Force KOPUR IV.

Untuk menyempurnakan organisasi serta hubungan Komando dalam pelaksanaan DWIKORA maka berdasarkan SK Presiden/Panglima KOTI No. 9/KOTI/1965 tertanggal 28 Pebruari 1965 Komando Siaga dirubah jadi KOMANDO MANDALA SIAGA dengan tugas pokok: "Merencanakan, mempersiapkan, melaksanakan, memimpin serta mengawasi operasi-operasi militer didalam rangka pelaksanaan DWIKORA pada khususnya juga mempertahankan wilayah Indonesia pada umumnya yang dilakukan didalam wilayah Pertahanan Barat".

Komando Mandala Siaga bersifat paduan (unified) yang meliputi wilayah Pertahanan Barat yaitu wilayah :
Darat : Daerah-daerah KODAM I, daerah KODAM IX, X, XI dan XII.

Daerah-daerah KODAMAR

Udara : I dan II, KOSIONAL, KOSETAL dan perairan terroterial di Sumatera dan Kalimantan dari KODAMAR III dan IV. Daerah Komando Regional Udara I dan II.

Adapun susunan pimpinan Komando Mandala Siaga ialah sebagai beikut:

1) Panglima KOLAGA : Laksamana Omar Dhani.

2) WAPANG KOLAGA I : Mayjen. TNI. Suharto.

3) WAPANG KOLAGA II : Laksda (L) Mulyadi.

4) Kepala Staf KOLAGA : Laksda (U) Leo Wattimena.

5) Wakas KOLAGA : Brigjen. TNI. A. Satari.

Dengan perubahan pimpinan tersebut maka diadakanlah berbagai perubahan dan konsepsi-konsepsi bagi pengembangan tugas-tugas KOLAGA. Akan tetapi sebaliknya perubahan pimpinan tersebut juga menimbulkan perselisihan paham, khususnya antara PANGKOLAGA dan WAPANG I, sampai WAPANG I Mayjen. Suharto menyampaikan permohonan berhenti sebagai Wakil Panglima KOLAGA kepada Presiden. Perselisihan paham ini kemudian dapat diselesaikan setelah Jenderal Nasution sendiri menyelesaikan secara baik dan diadakan pembagian tugas dan wewenang dimana WAPANG I diberikan wewenang untuk melaksanakan tugas-tugas operasi.

Pada pelaksanaan operasi dalam rangka konfrontasi terhadap Malaysia, KOLAGA selalu menggunakan dua sistem operasi yaitu sistem operasi Fisik dan Teknis (FISTEK) dan Sosial Politik (SOSPOL) sebagai sistem yang dilakukan oleh unsurunsur militer maupun non-militer. Dalam pelaksanaan operasi, kedua sistem tersebut dinamakan Operasi Militer dan Operasi Khusus.

Adapun Operasi Khusus ada 2 macam yang dilaksanakan KOLAGA adalah : 
1) Operasi khusus dilaksanakan KomandoKomando Satuan Tugas yang berwujud dalam rangka field-preparation.

2) "Staf Operasi Khusus" dibawah pimpinan Kolonel AM Murtopo yang langsung dikendalikan dan berada dibawah WAPANG I KOLAGA Mayjen. TNI Suharto.

Operasi Khusus dilaksanakan oleh Staf Operasi Khusus dilakukan dengan cara nonkonvensional melalui negara-negara lain dan berusaha mengadakan kontak langsung dengan tokoh-tokoh Malaysia untuk menjajagi kemungkinan penyelesaian konflik secara damai. Akan tetapi pendekatan-pendekatan yang dilakukan sebelum pemberontakan G-30S/PKI, tanggal 1 Oktober 1965 tidak mendapat sambutan dari kedua belah pihak oleh karena PKI tidak menginginkan terciptanya perdamaian Indonesia dan Malaysia.

Dalam rangka integrasi semua bentuk operasi DWIKORA dibawah KOLAGA maka sejak tanggal 8 Nopember 1964 wewenang operasi "A" (operasi intellijen) yang dulu dilaksanakan oleh KOTI dan BPI, diserahkan kepada KOLAGA. Akan tetapi pelaksanaan operasi "A" ini pun kurang banyak berhasil oleh karena sebelum putusnya hubungan diplomasi Indonesia dengan Malaysia di akhir tahun 1963, Indonesia tidak mempunyai data-data intellijen yang lengkap tentang Malaysia. Setelah hubungan diplomatik putus, operasi intellijen sangat sulit dilakukan karena sulitnya menerobos daerah Malaysia.

Pelaksanaan operasi intelijen ini kemudian dicapai dengan pelaksanaan operasi "Lintas Bebas" dengan menyusupkan sukarelawan-sukarelawan ke daerah lawan. Sukarelawan-sukarelawan ini disamping mengumpulkan data-data Intel, juga diberi tugas untuk menyusun kekuatan gerilyawan untuk berusaha menghancurkan kekuatan lawan dari dalam dengan melakukan sabotase serta gangguan keamanan. Dalam perjalanan operasi ini telah banyak jatuh korban kesuma bangsa dalam melakukan tugas negara.

\section{Akhir Konfrontasi}

Akhir tahun 1965, Jenderal Soeharto mulai memiliki kewenangan di bidang keamanan dan ketertiban, setelah berlangsungnya G30S/PKI. Konflik domestik ini, kemauan Indonesia untuk meneruskan perang dengan Malaysia menjadi berkurang, akhirnya peperangan pun mereda.
Tanggal 28 Mei 1966 sebuah konferensi diselenggarakan di Bangkok, Kerajaan Malaysia juga pemerintah Indonesia merumuskan penyelesaian konflik. Kekerasan berakhir resmi pada bulan Juni 1966, dan perjanjian perdamaian ditandatangani pada tanggal 11 Agustus 1966.

Pemulihan Hubungan negara Indonesia dengan Malaysia karena konfrontasi yang digelorakan oleh Presiden Soekarno, berakhir pada tahun 1967 sekaligus menggantikan posisi pemerintahan Soekarno, pasca peristiwa pemberontakan G-30 September, kemudian berganti menjadi pemerintahan Soeharto yang sekaligus merupakan awal mula dari pemerintahan Orde baru. Upaya menggalakkan pemulihan hubungan diplomasi Indonesia dengan Malaysia juga hubungan Indonesia dengan PBB dilakukan dengan kembali masuknya Indonesia dalam keanggotaan PBB.

\section{Politik Luar Negeri Republik Indonesia Pada Masa Konfrontasi Indonesia-Malaysia Tahun 1963-1966}

Beberapa kontroversi terus menyertai hubungan Indonesia-Malaysia sebelum zaman orde baru muncul, tepatnya pada tahun 19631966. Seperti diketahui, pada era kepemimpinan Soekarno, politik "Ganyang Malaysia" yang digelorakan untuk memberontak sekaligus menentang pembentukan persemakmuran Inggris, dan FM. Malaysia dinilai menjadi kaki tangan imperialisme barat. Dikuasai oleh Inggris. Kemudian, ide "Konfrontasi" yang bersifat radikal terhadap kebijakan luar negeri Indonesia dikeluarkan presiden Soekarno.

Hubungan Indonesia-Malaysia pertama kali dikenal dalam konstelasi politik regional, diawali dengan konfrontasi Indonesia-Malaysia. Persamaan rumpun suku melay, sejarah, letak geografis dan persamaan bahasa tidak mejamin Indonesia dan Malaysia menjalin hubungan yang sangat baik dan berlangsung secara harmonis, hubungan Indonesia dengan Malaysia sangatlah buruk ketika itu. Penyebarluasan imperialisme barat ini, menurut Presiden Soekarno dapat memberikan pengaruh negatif kepada kelangsungan negara-negara Asia Tenggara, akhirnya dibentuk suatu persepsi dan hubungan yang kurang baik dengan Malaysia. (John B. Sriyanto, $2010: 67$ )

Dilihat dari sisi positif, tindakan Presiden Soekarno melakukan konfrontatif kepada Malaysia sangat tepat. Sesuai dengan garis kebijakan politik luar negeri Indonesia; bebas aktif, Indonesia tidak menghendaki negara 
tetangganya menjadi antek-antek negara kolonialis dan imperialis. Apabila sebuah negara di wilayah Asia Tenggara sudah dikuasai oleh kekuatan kolonialis dan imperialis, maka wilayah tersebut akan dijadikan basis bagi penyebaran pengaruh mereka dan bahkan penguasaan mereka atas bangsa-bangsa dan negara-negara di sekitarnya.

Namun demikian, dilihat dari sisi negatif, konfrontasi ini telah menyebabkan bangsa Indonesia melenceng dari garis kebijakan luar negeri bebas dan aktif. Terbukti pada saat Indonesia menyatakan keluar dari PBB, dan setelah itu ada kesan bahwa bangsa Indonesia dikucilkan dari pergaulan dunia internasional.

Situasi kondisi bangsa Indonesia saat itu dimanfaatkan oleh PKI untuk kepentingan kemenangan golongan komunis Indonesia. Pada permulaan tahun 1965 situasi politik didalam negeri semakin memburuk yang diikuti dengan situasi sosial ekonomi yang semakin jelek. Politik konfrontatif terhadap Malaysia dianggap oleh Pemerintah Indonesia dewasa itu sebagai "Proyek Neo Kolonialisme" telah menyebabkan pemerintah Presiden Soekarno semakin keras melancarkan politik yang anti imperialisme dan anti kolonialisme yang menyebabkan pula Indonesia pada saat itu memusuhi negara-negara Barat. Politik Presiden Soekarno ini telah membuat kecenderungan ikut bekerja sama dengan negara komunis. Justru itulah yang diperhitungkan oleh PKI.

Situasi luar negeri dalam hubungan politik konfrontasi Indonesia semakin genting setelah pada bulan Januari 1965, Malaysia melaporkan kepada PBB tentang adanya bukti-bukti infiltrasi gerilyawan-gerilyawan Indonesia ke wilayah Mabysls, Situasi politik dalam negeri semakin memburuk setelah Presiden Soekarno semakin memperlihatkan politik membabi-butanya dengan ide-ide dan semboyan-semboyan politik konfrontasinya seperti "Berdiri di atas kaki sendiri", "Go to hell with your aids" (Amerika) dan lain-lain yang diikuti pula dengan tindakan keluarnya Indonesia dari PBB serta organisasi dunia lain pada bulan Januari 1965.

Tindakan pemerintah Presiden Soekarno ini mengakibatkan hilangnya dukungan luar negeri baik di bidang politik maupun ekonomi dan menjadikan Indonesia terisolir dari kehidupan bangsa-bangsa. Akibat selanjutnya, ialah negara-negara komunis seperti Rusia, Republik Rakyat Cina (RRC), Korea Utara dan lain-lain telah mendapat peluang baik untuk menanamkan pengaruhnya secara mendalam terhadap Indonesia, sehingga timbullah apa yang dinamakan "poros Jakarta - Hanoi - Peking Pyong Yang". RRT memberikan dukungannya secara penuh terhadap politik konfrontasi terhadap Malaysia, yang menguntungkan pihak komunis itu.

Di dalam negeri PKI telah memanfaatkan politik konfrontasi terhadap Malaysia. PKI merupakan partai yang dengan gigih menyokong pelaksanaan Dwikora. Ajakan Presiden Soekarno guna membentuk sukarelawan dalam rangka Dwikora telah disambut PKI dengan berusaha untuk menyusun pasukan sukarelawansukarelawan PKI untuk didrop ke daerah-daerah yang berbatasan dengan Malaysia. Kebijaksanaan pemerintah pada saat itu yang telah menerima sukarelawan tempur untuk diikutsertakan dalam operasi militer dari berbagai organisasi massa tanpa pengorganisasian dibawah disiplin TNI telah dimanfaatkan pula oleh PKI. Di daerah Kalbar pemerintah telah menerima dan melatih orangorang Cina Komunis pelarian dari Malaysia.Mereka ini lalu menjadi "sukarelawan Indonesia" menghadapi Malaysia. PKI telah mengirimkan sebanyak mungkin sukarelawansukarelawannya ke daerah Kalimantan Barat. Sukarelawan-sukarelawan komunis ini kemudian ternyata telah menjadi basis kekuatan pengacau di daerah Kalbar kemudian menjelma menjadi gerombolan Cina Komunis PGRS dan PARAKU.

Di kalangan ABRI, PKI berusaha sebanyak mungkin menanamkan pengaruhnya dengan mempengaruhi oknum-oknum TNI untuk menganut ide komunisme. Dengan menanam jaring-jaringnya didalam tubuh ABRI, PKI memperhitungkan untuk menghancurkan tokoh-tokoh TNI yang sangat anti terhadap PKI. Ofensif PKI ini kemudian lebih lantang lagi dengan mengemukakan gagasan pembentukan "Angkatan ke-V" terdiri dari buruh tani yang dipersenjatai.

Pada saat-saat TNI dengan seluruh bangsa Indonesia menunjukkan kesetiaannya terhadap pemerintah dan bangsa dalam melaksanakan politik konfrontasi dan Dwikora, maka tepat di tanggal 1 Oktober 1965 PKI telah mengkhianati garis perjuangan bangsa dengan mencetuskan pemberontakan Gerakan 30 September.

Bagi KOLAGA khususnya, pemberontakan G-30S/PKI merupakan pukulan yang sangat berat dan membawa pengaruh yang besar dalam pelaksanaan tugasnya. Sebagian tokoh-tokoh pimpinan KOLAGA telah terlibat 
langsung dengan pemberontakan G30S/PKI seperti Omar Dhani sebagai PANGKOLAGA beserta beberapa perwira stafnya, Supardjo sebagai Komandan KOPUR IV/Mandau yang mempunyai peranan penting dalam pelaksanaan tugas-tugas KOLAGA di Kalbar dan lain-lain.

Situasi Dwikora telah dimanfaatkan PKI guna kepentingan kaum komunis dengan menyusupkan sukarelawan-sukarelawan PKI di daerah perbatasan yang sedang dipersiapkan menghadapi Malaysia, menyusupkan tokohtokoh komunis di dalam ABRI, memanfaatkan situasi anti kolonialisme pemerintah Presiden Sukarno untuk menanamkan pengaruh PKI terhadap politik pemerintah dan mempersiapkan pematangan pemberontakan terhadap pemerintah Jakarta juga di daerah-daerah untuk merebut kekuasaan, justru pada saat-saat ABRI bersama rakyat Indonesia sedang mengabdi melaksanakan Dwikora. (John B. Sriyanto, 2010: 61)

Dalam menumpas pemberontakan G 30 S/PKI, Mayjen. Suharto sebagai PANGKOSTRAD dan sebagai WAPANG I KOLAGA tanggal 1 Oktober 1965 telah bertindak tegas menumpas pemberontakan, bersama dengan kekuatan ABRI dan rakyat yang setia negara dan Pancasila.

Dengan keterlibatan Omar Dhani di peristiwa G 30 S/PKI, maka sejak tanggal 21 Oktober 1965 Presiden telah menetapkan Mayjen Suharto sebagai Panglima KOLAGA. Untuk meningkatkan kegiatan KOLAGA dalam pelaksanaan Dwikora, maka Mayjen Suharto telah merubah struktur organisasi KOLAGA menjadi sistem Komponen, untuk memberikan peranan dan wewenang yang besar kepada Angkatan dalam pelaksanaan operasi.

\section{SIMPULAN}

Hasil pembahasan Konfrontasi Indonesia dengan Malaysia atau Konfrontasi ialah sebuah perang tentang masa depan Malaya, Brunei, Sabah dan Sarawak yang terjadi antara Federasi Malaysia dan Indonesia pada tahun 1963 hingga 1966.

Perang ini dimulai karena keinginan Federasi Malaya (FM) lebih dikenal dengan Persekutuan Tanah Melayu pada tahun 1961. Namun penggabungan Brunei, Sabah dan Sarawak ke dalam Federasi Malaysia tidak sesuai dengan Persetujuan Manila. Maka penggabungan FM tersebut ditentang oleh Presiden Soekarno. Pembentukan Federasi
Malaysia yang sekarang dikenal sebagai Malaysia ialah "boneka imperialisme Inggris" yang kolonialisme dan imperialisme gaya baru.

Tanggal 3 Mei 1964 rapat besar yang dilaksanakan di Senayan, Jakarta. Soekarno mengumumkan perintah Dwi Komando Rakyat (Dwikora) yang isinya; pertinggi ketahanan revolusi Indonesia dan membantu perjuangan rakyat Malaya, Singapura, Sarawak dan Sabah, untuk menghancurkan Federasi Malaysia.

Menjelang akhir tahun 1965, Jenderal Soeharto mulai memiliki kewenangan di bidang keamanan dan ketertiban, setelah berlangsungnya G30S/PKI. Konflik domestik ini, semangat Indonesia untuk meneruskan perlawanan kepada Malaysia menjadi berkurang hingga akhirnya mereda.

Tanggal 28 Mei 1966 konferensi di Bangkok, merumuskan antara Kerajaan Malaysia dan pemerintah Indonesia tentang penyelesaian konflik. Kekerasan berakhir bulan Juni 1966, dan perjanjian perdamaian ditandatangani pada tanggal 11 Agustus 1966.

Politik luar negeri Indonesia pada masa konfrontasi Indonesia dengan Malaysia tahun 1963-1966 melenceng dari garis politik luar negeri bebas aktif. Namun jika dilihat dari sisi positif, tindakan Presiden Soekarno melakukan konfrontasi kepada Malaysia sangat tepat. Sesuai dengan garis kebijakan politik luar negeri Indonesia yang bebas aktif, Indonesia tidak menghendaki negara tetangganya menjadi antek-antek negara kolonialis dan imperialis. Apabila sebuah negara di Asia Tenggara dapat dikuasai oleh kekuatan kolonialis dan imperialis, maka wilayah tersebut akan dijadikan basis bagi penyebaran pengaruh mereka dan bahkan penguasaan mereka atas bangsa-bangsa dan negara-negara di sekitarnya.

Namun demikian, dilihat dari sisi negatif, konfrontasi ini telah menyebabkan bangsa Indonesia melenceng dari garis kebijakan politik luar negeri bebas dan aktif. Terbukti pada waktu itu Indonesia menyatakan keluar dari keanggotaan di PBB, dan setelah itu ada kesan bahwa bangsa Indonesia dikucilkan dari pergaulan dunia internasional. Selain itu pula, peristiwa konfrontasi Indonesia-Malaysia ini dimanfaatkan oleh PKI untuk kepentingannya mendekatkan negara Indonesia dengan negaranegara komunis seperti USSR, Korea Utara dan RRC. 


\section{DAFTAR PUSTAKA}

Abdul Haris Nasution (1966). Sejarah Perjuangan Nasional di Bidang Bersenjata. Jakarta : Mega Bookstore.

Departemen Penerangan RI (1964). Gelora Konfrontasi Mengganyang Malaysia. Jakarta.

Dinas Sejarah TNI Angkatan Darat (1972). Cuplikan Sejarah Perjuangan TNI Angkatan Darat. Jakarta: Fakta Mahjuma.

Gottchalk, Louis (1983). Mengerti Sejarah. Jakarta: UI Press.

Ismaun. (1984). Pengantar Ilmu Sejarah. Bandung: Jurusan Pendidikan Sejarah FPIPS-IKIP.

John B. Srijanto. (2010). Ganyang Malaysia. Politik Konfrontasi Bung Karno. Yogyakarta: InterpreBook.

Kusumah, Hadiningrat. (1971). Sedjarah Operasi-Operasi Gabungan Dalam Rangka Dwikora. Jakarta: Departemen Pertahanan dan Keamanan, Pusat Sedjarah ABRI.

Leifer, Michael. (1989). Politik Luar Negeri Indonesia. Jakarta: Gramedia.

Sekretariat Negara RI. (1981). 30 Tahun Indonesia Merdeka. 1950-1964. Jakarta: Citra Lamtoro Gung Persada. (1986). 30 Tahun Indonesia Merdeka. 1965-1973. Jakarta: Citra Lamtoro Gung Persada.

Majalah Angkasa, Edisi II Tahun 2006. 